Terakreditasi: SK No.: 60/E/KPT/2016

Website : http://ejournal.undip.ac.id/index.php/reaktor/

Reaktor, Vol. 16 No. 4, Desember Tahun 2016, Hal. 189-198

\title{
Sintesis Biomaterial Hydroxyapatite dengan Proses Flame Spray Pyrolysis Disertai Penambahan Aditif Organik
}

\author{
Adhi Setiawan $^{\left.1^{*}\right)}$, Widiyastuti ${ }^{2)}$, Sugeng Winardi' ${ }^{2}$, dan Agung Nugroho ${ }^{1)}$ \\ ${ }^{1)}$ Politeknik Perkapalan Negeri Surabaya (PPNS) \\ Jl. Teknik Kimia Kampus ITS Sukolilo 60111-Indonesia \\ Telp./Fax. (031)5947186 / (031)5942887 \\ 2) Jurusan Teknik Kimia, Fakultas Teknologi Industri Institut Teknologi Sepuluh Nopember Surabaya \\ Kampus Keputih ITS Sukolilo 60111-Indonesia \\ *)Penulis korespondensi : adhistw23@gmail.com
}

\begin{abstract}
SYNTHESIS OF HYDROXYAPATITE BIOMATERIALS BY FLAME SPRAY PYROLYSIS PROCESS WITH ADDITION OF ORGANIC ADDITIVES. Hydroxyapatite is biomaterial which is widely used for biomedical application such as implant because biocompatible, bioactivity, and strong affinity to biopolymers. Therefore parameters of morphology and crystallinity becomes an important parameter to be controlled. The addition of the organic additive on HAp precursor with ethylene glycol, polyethylene glycol 400, and urea is the alternative to improve the size, morphology, and crystallinity of HAp particles. The equipment for flame spray pyrolysis process includes ultrasonic nebulizer, flame reactor, and electrostatic precipitator. The amount of organic additives used in experiment is 30, 50, and 100\% by mass of the precursor. The result of SEM and XRD showed HAp synthesized by the addition of additive material has a smaller size than without using the additive and crystallinity is better than no additive. In addition HAp synthesized by the addition of $30 \%$ PEG additive have smallest average particle size about $114 \mathrm{~nm}$, crystalite size about $16.6 \mathrm{~nm}$ and spherical morphology with a low agglomeration.
\end{abstract}

Keywords: organic additives; flame spray pyrolysis; hydroxyapatite; morfology

\begin{abstract}
Abstrak
Hydroxyapatite merupakan biomaterial yang seringkali diaplikasikan dalam biomedis sebagai bahan implant karena sifatnya yang biocompatible, bioactivity, dan memiliki afinitas yang kuat terhadap biopolimer. Oleh karena itu parameter morfologi serta kristalinitas partikel menjadi parameter penting untuk dikontrol. Penambahan aditif organik pada prekursor HAp dengan etilen glikol, polietilen glikol 400, serta urea merupakan alternativ agar memperbaiki ukuran, morfologi, serta meningkatkan kristalinitas partikel HAp. Peralatan utama flame spray pyrolysis meliputi ultrasonic nebulizer, reaktor flame, dan eletrostatik precipitator. Jumlah aditif organik yang digunakan pada eksperimen antara lain 30, 50, dan 100\% massa prekursor. Hasil SEM dan XRD menunjukkan bahwa HAp yang disintesis dengan penambahan bahan aditif memiliki ukuran lebih kecil daripada tanpa menggunakan aditif dan tingkat kristalinitasnya lebih baik dibandingkan tanpa aditif. Selain itu HAp yang disintesis dengan penambahan aditif PEG sebanyak 30\% memiliki ukuran rata-rata partikel yang terkecil yaitu sebesar $114 \mathrm{~nm}$ dengan ukuran kristal mencapai 16,6 $\mathrm{nm}$ serta memiliki morfologi bulat dengan tingkat aglomerasi yang rendah.
\end{abstract}

Kata kunci: aditif organic; flame spray pyrolysis; hydroxyapatite; morfology 
How to Cite This Article: Setiawan, A., Widiyastuti, Winardi, S., dan Nugroho, A., (2016), Sintesis Biomaterial Hydroxyapatite dengan Proses Flame Spray Pyrolysis disertai Penambahan Aditif Organik, Reaktor, 16(4), 189-198, http://dx.doi.org/10.14710/reaktor.16.4.189-198

\section{PENDAHULUAN}

Hydroxyapatite atau yang disebut HAp merupakan material yang seringkali digunakan di dalam aplikasi biomedis sifatnya yang biocompatible, bioactivity, dan memiliki afinitas yang relatif kuat terhadap biopolimer (Cho dan Kang, 2008). Rumus molekul hidroxypapatite berupa $\mathrm{Ca}_{10}\left(\mathrm{PO}_{4}\right)_{6}(\mathrm{OH})_{2}$ dengan struktur kristal hexagonal dipyramidal. HAp memiliki specific gravity 3,08 serta berbentuk serbuk yang berwarna putih. Di dalam dunia biomedis, material HAp memiliki peranan yang penting karena dapat meregenerasi cacat tulang yang diakibatkan oleh kecelakaan. Pada umumnya bagian tulang yang rusak akibat kecelakaan akan digantikan dengan implant logam atau diisi dengan material bioactive (Ataol dkk., 2015; Paital dan Dahotre, 2009). Hydroxyapatite juga banyak digunakan untuk memperbaiki dan merekontruksi bagian tulang manusia yang rusak terutama sebagai tulang pengganti dalam pengisian tulang (Descamps dkk., 2008). Ketika HAp diimplankan di dalam tubuh manusia, kalsium di dalam HAp memberikan kontribusi pada pengikatan HAp pada jaringan tulang yang hidup (An dkk., 2007). Selain penggunaannya di dunia biomedis, material HAp juga dapat digunakan sebagai material penukar ion yang dapat memisahkan kandungan ion logam berat yang berbahaya di dalam air limbah (Suzuki dkk., 1993).

Hidroxyapatite pada umumnya dapat disintesis dengan beberapa metode yaitu metode basah (wet base method), metode kering (dry base method), dan proses temperatur tinggi (Cho dan Rhee, 2013; Sadat dkk., 2013; Setiawan dkk., 2014). Metode basah terdiri dari metode presipitasi kimia, sol gel, dan hidrolisis. Metode kering terdiri dari metode solid state, sintesis mekano-kimia. Metode basah seperti sol gel, hidrotermal, dan presipitasi seringkali diaplikasikan dalam sintesis HAp karena relatif mudah diterapkan, murah, temperatur proses relatif rendah, serta menghasilkan air sebagai produk samping (Ataol dkk., 2015; Cho dan Rhee, 2013; 'Slósarczyk dkk., 1996). Metode basah pada umumnya tidak menggunakan pelarut organik sehingga dari sisi efektivitas biaya relatif murah dan ramah lingkungan (Mohn dkk., 2011). Namun penggunaan metode basah memiliki beberapa kelemahan yaitu morfologi dan ukuran partikel produk sangat dipengaruhi oleh parameter eksternal seperti temperatur dan $\mathrm{pH}$ larutan, kemurnian dan kristalinitas produk HAp yang rendah (Cho dkk., 2009). Pada Metode kering melibatkan pencampuran bubuk prekursor kering yang dilanjukan dengan tahapan milling dan sintering campuran prekursor pada temperatur tinggi (Tofighi dan Palazzolo, 2005). Metode kering memiliki kelebihan yaitu produk yang dihasilkan memiliki kristalinitas yang tinggi. Namun metode tersebut memiliki yield yang relatif lebih rendah dibandingkan dengan metode basah dan menghasilkan partikel dengan morfologi yang tidak teratur serta ukuran yang besar (Cho dan Kang, 2008; Sadat dkk., 2013). Bahkan produk HAp yang disintesis dengan metode kering memiliki kompatibilitas yang rendah atau cukup sulit berinteraksi dengan cairan tubuh ketika diaplikasikan dalam biomedis (Zhou dan Lee, 2011).

Sintesis HAp dapat dilakukan dengan menggunakan proses temperatur tinggi antara lain dengan metode spray pyrolysis dan flame spray pyrolysis (Cho dan Rhee, 2013). Spray pyrolysis memiliki beberapa kelebihan diantaranya prosesnya produksi partikel berlangsung secara kontinyu, partikel produk berbentuk bola, homogen, tidak membentuk agregat, dan distribusi ukuran seragam (Cho dan Kang, 2008). Namun sintesis dengan metode spray pyrolysis memiliki kelemahan antara lain kemungkinan terbentuknya partikel hollow cukup besar hal ini disebabkan penggunaan sumber pemanas furnace sehingga distribusi temperatur hampir seragam sepanjang reaktor. Hal ini menyebabkan evaporasi pelarut di dalam droplet menjadi lebih cepat (Widiyastuti dkk., 2007). Selain itu, ukuran produk sangat ditentukan oleh ukuran droplet dan konsentrasi yang prekursor yang masuk ke reaktor (Okuyama dan Lenggoro, 2003). Oleh karena itu, spray pyrolysis hanya dapat diaplikasikan pada konsentrasi prekursor yang relatif rendah agar diperoleh partikel berukuran nanometer sehingga dapat menurunkan laju produksi.

Produksi nanopartikel dengan metode spray pyrolysis pada konsentrasi larutan prekursor yang tinggi dengan penambahan aditif organik merupakan strategi untuk memproduksi partikel berukuran nanometer. Penambahan aditif pada spray pyrolysys dilakukan untuk memperbaiki karakteristik dari partikel. Namun penggunaan aditif organik pada spray pyrolysis dinilai kurang efektif. Hal ini disebabkan temperatur operasi reaktor spray pyrolysis relatif rendah bila dibandingkan dengan temperatur yang dihasilkan dengan metode flame. Bahkan metode spray pyrolysis memiliki laju pemanasan prekursor yang relatif rendah dibandingkan dengan metode flame spray pyrolysis sehingga dekomposisi bahan aditif organik berlangsung kurang sempurna (Purwanto dkk., 2008 ; Cho dan Rhee, 2013; Itatani dkk., 2004). Proses dekomposisi yang kurang sempurna dari aditif organik tersebut menyebabkan timbulnya kontaminasi produk dan menghasilkan partikel dengan ukuran mikrometer akibat tekanan gas hasil dekomposisi yang tidak cukup kuat menekan dinding partikel agar terpecah (Cho dan Rhee, 2013).

Metode sintesis partikel dengan flame spray pyrolysis memiliki beberapa keunggulan bila dibandingkan dengan metode spray pyrolysis antara lain memiliki temperatur yang relatif tinggi, kristalinitas dan kemurnian produk yang tinggi, waktu tinggal partikel yang relatif sangat singkat hanya 
beberapa milidetik bila dibandingkan dengan spray pyrolysis yang memiliki waktu tinggal dalam orde detik dengan metode basah (sol gel) berlangsung hingga 12-15 jam. Hal ini memungkinkan produksi partikel berukuran nanometer pada skala besar (Pratsinis, 1998; Fathi dkk., 2008). Proses flame memiliki temperatur dan laju pemanasan yang tinggi sehingga memungkinkan reaksi psikokimia di dalam prekursor berlangsung secara cepat (Purwanto dkk., 2008). Dengan kondisi tersebut memungkinkan dekomposisi material organik dapat berlangsung secara cepat dan sempurna menghasilkan gradien tekanan gas yang cukup besar di dalam partikel yang mampu memecah dinding partikel sehingga mengarah pada pembentukan partikel berukuran nanometer.

Pada penelitian sebelumnya Trommer dkk. (2009) berhasil mensintesis partikel HAp dengan metode flame spray pyrolysis dengan menggunakan prekursor kalsium asetat dan ammonium phosfat pada rasio molar $\mathrm{Ca} / \mathrm{P}$ sebesar 1,67 disertai penambahan aditif etanol dan proses annealing HAp pada temperatur $600^{\circ} \mathrm{C}$ selama 2 jam. Hasil penelitian menunjukkan morfologi partikel HAp berbentuk aggregat dengan ukuran kristal rata-rata $24 \mathrm{~nm}$. Itatani dkk. (2004) mempelajari proses pembentukan partikel pada spray pyrolysis pada temperatur yang tinggi menyebabkan partikel HAp memiliki morfologi berbentuk bola dengan struktur hollow serta partikel teraglomerasi. An dkk (2007) berhasil mensintesis partikel HAp nanopartikel dengan penambahan aditif garam natrium nitrat $\left(\mathrm{NaNO}_{3}\right)$ pada prekursor larutan kalsium fosfat. Purwanto dkk (2008) mensintesis partikel YAG-Ce dengan metode flame spray pyrolysis disertai aditif urea pada prekursor dan menghasilkan partikel dengan morfologi nanometer, menggumpal, serta tingkat kemurnian yang tinggi. Cho dkk (2009) meneliti mekanisme pembentukan HAp dengan proses spray pyrolysis dengan penambahan PEG 10000 pada larutan prekursor. hasil penelitian menunjukkan adanya sisa karbon akibat PEG sehingga perlu dilakukan pemanasan pada $650^{\circ} \mathrm{C}$ selama 3 jam untuk menghilangkan pengotornya. Ataol dkk (2015) melaporkan bahwa kristalinitas dan luas permukaan spesifik partikel dari HAp yang disintesis dari prekursor larutan kalsium acetat dan tributil phosfat menggunakan metode flame spray pyrolysis sebanding dengan rasio dari $\mathrm{mol} \mathrm{Ca} / \mathrm{P}$.

Pada dasarnya penambahan aditif dilakukan untuk memperoleh partikel berukuran nano dan memperbaiki karakteristik dari partikel produk. Hal ini disebabkan penambahan aditif secara langsung menyebabkan dekomposisi bahan organik menghasilkan tekanan gas yang mengarah pada pecahnya partikel ke ukuran nano serta peningkatan suhu flame (Purwanto dkk., 2008). Pada penelitian sebelumnya penggunaan aditif hanya terbatas pada bahan etanol dan PEG 10000 dan $\mathrm{NaNO}_{3}$. Penggunaan etanol sebagai aditif pada proses flame spray pyrolysis memiliki kelemahan yaitu sifatnya yang mudah terbakar dan membahayakan bila menggunakan nebulizer sebagai proses atomisasi larutan prekursornya sehingga hanya direkomendasikan pada konsentrasi rendah. Selain itu penggunaan aditif PEG 10000 memiliki berat melekul yang relatif tinggi sehingga pada sintesis HAp menyebabkan kontaminasi jika suhu operasi terlalu rendah dan membutuhkan pemanasan ulang untuk menghilangkan sisa kontaminan karbon. Bahkan penggunaan PEG 10000 pada konsentrasi tinggi menyebabkan viskositas larutan prekursor meningkat dan menyebakan ukuran droplet saat atomisasi menjadi lebih besar. Penggunaan aditif $\mathrm{NaNO}_{3}$ menyebabkan kontaminasi garam Na pada HAp sehingga partikel perlu dilakukan pembilasan dengan air untuk memisahkan $\mathrm{Na}$ dari partikel (An dkk., 2007; Cho dan Rhee, 2013). Pada penelitian ini difokuskan pada sintesis partikel HAp dengan metode flame spray pyrolysis disertai dengan penambahan aditif organik seperti urea, etilenglikol, dan PEG 400 yang belum dilakukan oleh peneliti terdahulu terutama dalam mensintesis partikel HAp dengan metode flame spray pyrolysis. Beberapa kelebihan yang dimiliki oleh ketiga aditif tersebut antara lain ekonomis serta dapat terdekomposisi pada temperatur operasi flame sehingga tidak memerlukan post treatment tambahan. Dengan mengatur jumlah aditif organik tersebut pada prekursor dapat memodifikasi ukuran, morfologi produk, dan memperbaiki kristalinitas partikel (Vidyasagar dan Naik, 2016). Dengan pemakaian aditif diharapkan dapat mereduksi ukuran partikel dan meningkatkan kristalinitas HAp. Stanley (2014) melaporkan bahwa dengan mereduksi ukuran HAp dan meningkatkan kristalinitas akan meningkatkan dan memperbaiki adhesi sel hidup pada material. Sebagai prekursor sintesis HAp pada penelitian ini menggunakan larutan kalsium nitrat dan diammonium hidrogen phosfat dengan perbandingan mol Ca/p 1,67. Selain itu akan dianalisis bagaimana pengaruh penambahan aditif tersebut terhadap morfologi dan tingkat kristalinitas dari partikel. Diharapkan dengan penelitian ini dapat memberikan informasi tentang pengaruh penambahan aditif organik pada sintesis HAp terhadap morfologi dan kristalinitas HAp terutama dalam proses produksi skala besar di industri dengan metode flame spray pyrolysis.

\section{METODE PENELITIAN}

Material HAp yang disintesis dengan menggunakan metode flame spray pyrolysis disintesis dari larutan kalsium fosfat dengan rasio mol $\mathrm{Ca} / \mathrm{P}$ sebesar 1,67. Besarnya konsentrasi larutan prekursor yang digunakan dalam sintesis HAp sebesar 0,1 mol/liter. Larutan ini dibuat dengan cara melarutkan 14,75 g kristal $\mathrm{Ca}\left(\mathrm{NO}_{3}\right)_{2} .4 \mathrm{H}_{2} \mathrm{O}(99,99 \%$ berat Merck $\mathrm{KGaA}$, Germany) dan 4,95 g $\left(\mathrm{NH}_{4}\right)_{2} \mathrm{HPO}_{4}(99,99 \%$ berat Merck KGaA, Germany) dalam $1000 \mathrm{ml}$ air. Setelah terbentuk larutan kalsium fosfat, maka ditambahkan 2,4 ml larutan $\mathrm{HNO}_{3}(60 \%$ berat Merck KGaA, Germany) dengan tujuan untuk melarutkan seluruh endapan dari kalsium fosfat yang terbentuk. 
Setelah terbentuk larutan prekursor selanjutnya dilarutkan satu jenis aditif dari tiga jenis aditif yang akan digunakan. Bahan aditif yang ditambahkan pada prekursor antara lain berupa urea $(99 \%$ berat Merck KgaA, Germany), etilenglikol (99\% berat Merck KGaA, Germany) dan polietilen glikol atau PEG (99\% berat Merck KGaA, Germany) berat molekul 400 . Variasi penambahan aditif yang digunakan antara lain 30 , 50, dan $100 \%$ dari total massa prekursor yang dilarutkan.

Larutan prekursor yang mengandung aditif tersebut selanjutnya dinebulasi menggunakan ultrasonic nebulizer (OMRON NE-U17, Jepang) untuk menghasilkan droplet yang akan dialirkan bersama dengan gas pembawa (carrier gas) menuju reaktor diffusion flame seperti pada Gambar 1. Gas pembawa dalam hal ini berupa udara pada laju alir $1 \mathrm{~L} / \mathrm{min}$. Energi panas didalam reaktor flame dihasilkan melalui pembakaran bahan bakar LPG $12 \mathrm{~kg}$ yang diproduksi PT. Pertamina dengan udara sebagai oxidizernya. Laju alir dari gas LPG dan oxidizer diatur dengan menggunakan flow meter (KUFLOC RK 1200, Jepang) masing-masing sebesar 1,5 dan $3 \mathrm{~L} / \mathrm{min}$. Gas hasil pembakaran selanjutnya dialirkan menuju electrostatic precipitator yang berfungsi sebagai penangkap partikel sehingga partikel dapat terpisah dari flue gas. Gas hasil pembakaran selanjutnya dialirkan menuju pendingin untuk diturunkan suhunya sehingga terbentuk kondensat yang ditampung dalam water trap. Sedangkan penggunaan pompa vakum (Vacuum Krisbow PUMP 1/3 HP) untuk menghisap gas dalam tabung sehingga sirkulasi gas menjadi lebih lancar.

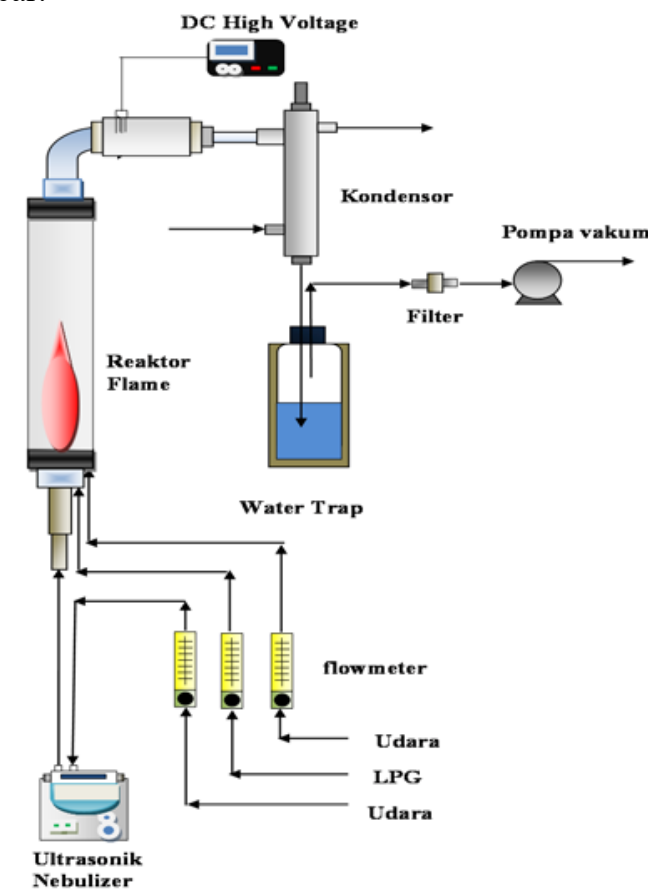

Gambar 1. Set Up peralatan Flame Spray Pyrolysys

Partikel yang dihasilkan pada eksperimen ini terkumpul dalam electrostatic precipitator berupa serbuk untuk selanjutnya dianalisa morfologi dan derajat kristalnya. Analisa kemurnian dan derajat kristalnya menggunakan XRD ( $X$-ray Diffraction) X'Pert RINT $2200 \mathrm{~V}$ Philiph $\mathrm{CuK} \alpha(\lambda=1,5418 \AA)$. Analisis XRD pada HAp dilakukan interval sudut $10^{\circ}$ $60^{\circ}$ dengan lebar step $0,01^{\circ}$ dan laju scan $0,5 \mathrm{~s} / \mathrm{step}$. Ukuran kristal dari partikel HAp berdasarkan analisa XRD dihitung dengan persamaan Debye-Scherrer (Vidyasagar dan Naik, 2016) sebagai berikut:

$$
D_{c}=\frac{0,9 \cdot \lambda}{B \cdot \operatorname{Cos} \theta}
$$

Dengan $\lambda$ merupakan panjang gelombang XRD $(0,154$ $\mathrm{nm}$ ), $\theta$ sudut difraksi, dan B merupakan FWHM (full width at half maksimum) atau lebar puncak pada setengah intensitas maksimum dalam radian. Sedangkan untuk morfologi dan ukuran partikel dianalisis dengan menggunakan SEM (Scanning Electron Microscope) Zeiss Evo MA LS series dioperasikan pada $20 \mathrm{KV}$.

Sifat termal dari bahan aditif etilen glikol, Polietilen glikol, dan urea dianalisis dengan menggunakan metode TG-DTA (DTG-60H, Shimadzu). Pada prinsipnya analisis TG-DTA (Thermogravimetry and Differential Thermal Analysis) dapat mencatat perubahan massa dan panas material secara simultan selama proses pemanasan sehingga dapat diketahui temperatur dekomposisi material tersebut. Laju pemanasan pada analisis TGDTA tersebut sebesar $10^{\circ} \mathrm{C} /$ menit dengan massa bahan aditif sebanyak $4 \mathrm{mg}$. Analisis TG-DTA dilakukan pada interval temperatur $25-600^{\circ} \mathrm{C}$ dengan atmosfer nitrogen pada laju alir $50 \mathrm{ml} / \mathrm{min}$ serta menggunakan pan aluminium sebagai tempat sampelnya.

\section{HASIL DAN PEMBAHASAN Analisis Sifat Termal Bahan Aditif}

Gambar 2 menunjukkan grafik TG-DTA untuk bahan aditif urea. Dari grafik TG menunjukkan bahwa pemanasan menyebabkan terjadinya penurunan massa akibat proses dekomposisi yang terjadi urea. Proses dekomposi dapat ditunjukkan dari grafik TG urea yang dimulai pada interval temperatur $130-400^{\circ} \mathrm{C}$. Pemanasan pada temperatur $130^{\circ} \mathrm{C}$ menyebabkan urea meleleh sebagaimana ditunjukkan munculnya peak pada grafik DTA. Pada temperatur $240^{\circ} \mathrm{C}$ urea akan terdekomposisi menjadi biuret dan produk volatil sehingga terjadi penurunan massa sampel menjadi $30 \%$ dari massa mula-mula.

Hal ini dapat diverifikasi dengan munculnya peak grafik DTA pada suhu $240^{\circ} \mathrm{C}$. Selain itu, dari grafik DTA pada suhu sekitar $370^{\circ} \mathrm{C}$ mendeteksi peak yang disebabkan oleh dekomposisi menjadi asam cyanuric, ammelamide, melamin (Schaber dkk., 2004).

Dari proses dekomposisi tersebut terjadi penurunan massa urea hingga menjadi 3\% dari massa awal. Proses dekomposisi sempurna terjadi pada suhu $400^{\circ} \mathrm{C}$. Reaksi keseluruhan dari sampel urea akibat adanya proses pemanasan dengan adanya air dapat ditulis sebagaimana (Purwanto dkk., 2008):

$$
\mathrm{NH}_{2} \mathrm{CONH}_{2}+\mathrm{H}_{2} \mathrm{O} \longrightarrow 2 \mathrm{NH}_{3}+\mathrm{CO}_{2}
$$


Dari hasil analisis DTA menunjukkan bahwa dalam proses dekomposisi urea tersebut akan dilepaskan panas sebesar 10,836 J/mg.

Gambar 3 menunjukkan grafik TG-DTA untuk bahan aditif etilen glikol (EG). Pemanasan pada suhu $200^{\circ} \mathrm{C}$ menyebabkan etilen glikol mencapai titik didihnya. Hal ini menyebabkan terjadinya penguapan etilen glikol dari fasa liquid menjadi fase uap. Dari perubahan fase tersebut menyebabkan pada terjadinya kehilangan massanya mendekati $100 \%$. Dapat dilihat bahwa sampel EG akan terdekomposisi pada suhu $200^{\circ} \mathrm{C}$ dan panas yang dilepaskan sebesar $3,885 \mathrm{~J} / \mathrm{mg}$.

Selain itu pada temperatur tinggi dekomposisi termal dari etilen glikol terjadi dengan reaksi dekomposisi global sebagai berikut:

$$
\mathrm{C}_{2} \mathrm{H}_{4}(\mathrm{OH})_{2} \longrightarrow 2 \mathrm{CO}_{2}+3 \mathrm{H}_{2} \mathrm{O}
$$

Gambar 4 menunjukkan grafik TG-DTA untuk bahan aditif PEG 400. Dekomposisi dari sample PEG dimulai pada temperatur $200^{\circ} \mathrm{C}$ dan mencapai dekomposisi sempurna pada temperatur sekitar $380^{\circ} \mathrm{C}$. Hal ini dapat ditunjukkan dari grafik TG pada interval suhu tersebut terjadi penurunan massa yang cukup signifikan sehingga dapat diindikasikan bahwa telah terjadi reaksi dekomposisi PEG tersebut (Wang dkk., 2007).

Dekomposisi PEG diasumsikan terjadi pada ikatan -C-O- dan -C-C- dan PEG memiliki struktur ikatan rantai lurus yang terdiri dari $66 \%$ ikatan -C-Odan 33\% ikatan -C-C- dengan energi ikatan yang hampir sama besarnya dengan range $82-83 \mathrm{Kcal} / \mathrm{mol}$. Dekomposisi dari PEG menghasilkan gas $\mathrm{CO}_{\mathrm{x}} \mathrm{H}_{\mathrm{y}}, \mathrm{H}_{2}$,

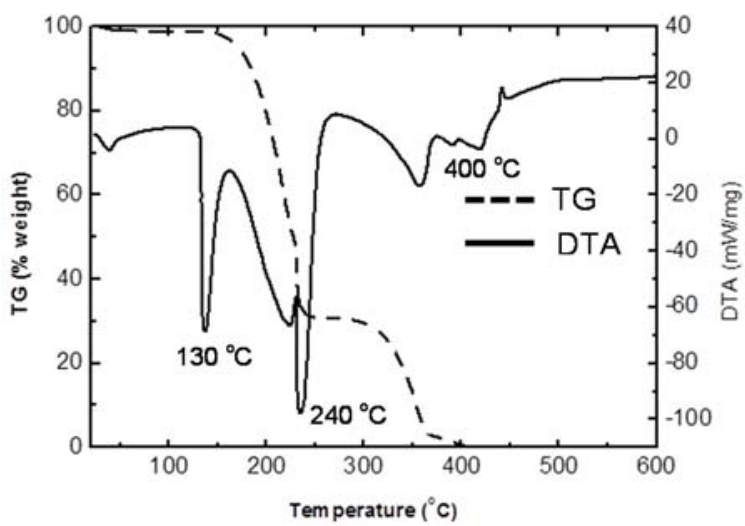

Gambar 2. TG-DTA dari sampel urea

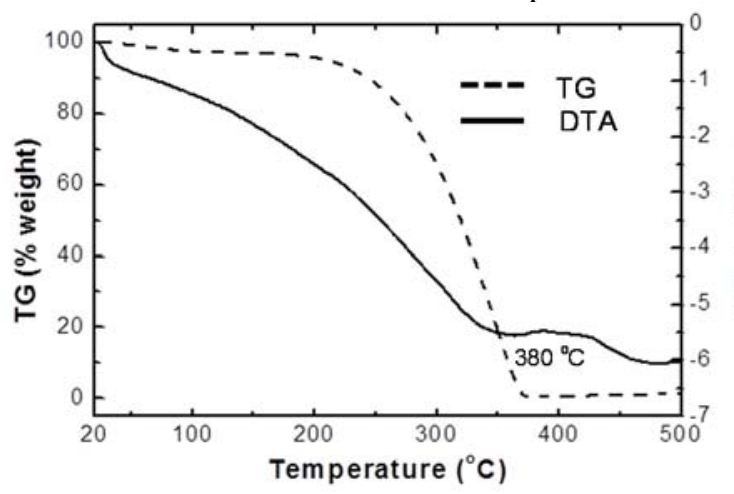

Gambar 4. TG-DTA dari sample PEG 400 dan $\mathrm{H}_{2} \mathrm{O}$ (Kwon, 2006). Besarnya panas yang dilepaskan dari analisa DTA untuk sample PEG 400 sebesar $12,213 \mathrm{~J} / \mathrm{mg}$

Dari nilai suhu dekomposisi dan panas pembakaran yang dibebaskan dapat dilihat bahwa semakin besar berat molekul aditif, maka suhu dekomposisi dan panas pembakaran semakin meningkat.

\section{Analisis SEM dan XRD}

Gambar 5 menunjukkan morfologi dari partikel HAp yang disintesis tanpa melalui penambahan aditif. Hasil SEM tersebut menunjukkan bahwa morfologi partikel yang seragam berbentuk bulat dense, tidak teraglomerasi, serta memiliki diameter berkisar antara $0,4 \mu \mathrm{m}-1,3 \mu \mathrm{m}$. Adanya perbedaan ukuran ini disebabkan droplet yang dihasilkan oleh ultrasonik nebulizer tidak memiliki ukuran yang seragam sehingga ketika memasuki reaktor flame akan memiliki laju penguapan pelarut yang berbeda (Rajan dan Pandit, 2001). Droplet dengan ukuran yang lebih kecil akan menghasilkan laju evaporasi pelarut dan dekomposisi prekursor yang lebih cepat bila dibandingkan dengan droplet yang berukuran besar sehingga akan dihasilkan ukuran partikel HAp yang tidak seragam. Selain itu distribusi temperatur dalam reaktor flame yang berbeda baik dalam arah aksial maupun arah radial yang juga memberikan kontribusi terhadap laju evaporasi droplet yang berbeda sehingga mengarah pada perbedaan ukuran partikel (Widiyastuti dkk., 2010).

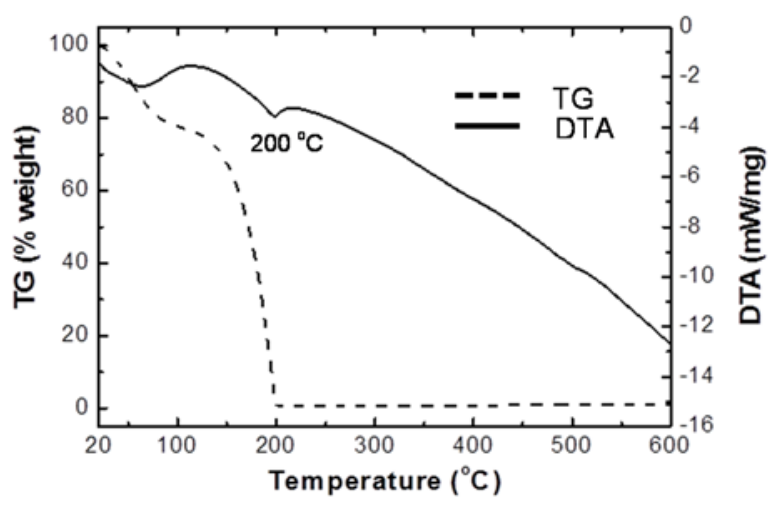

Gambar 3. TG-DTA dari sample etilen glikol (EG)

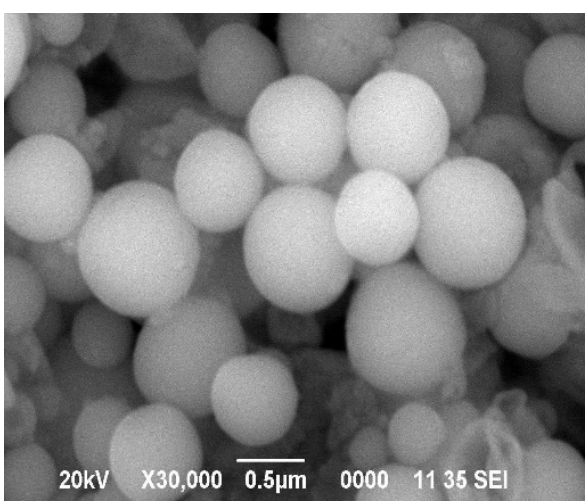

Gambar 5. SEM HAp tanpa penambahan aditif 


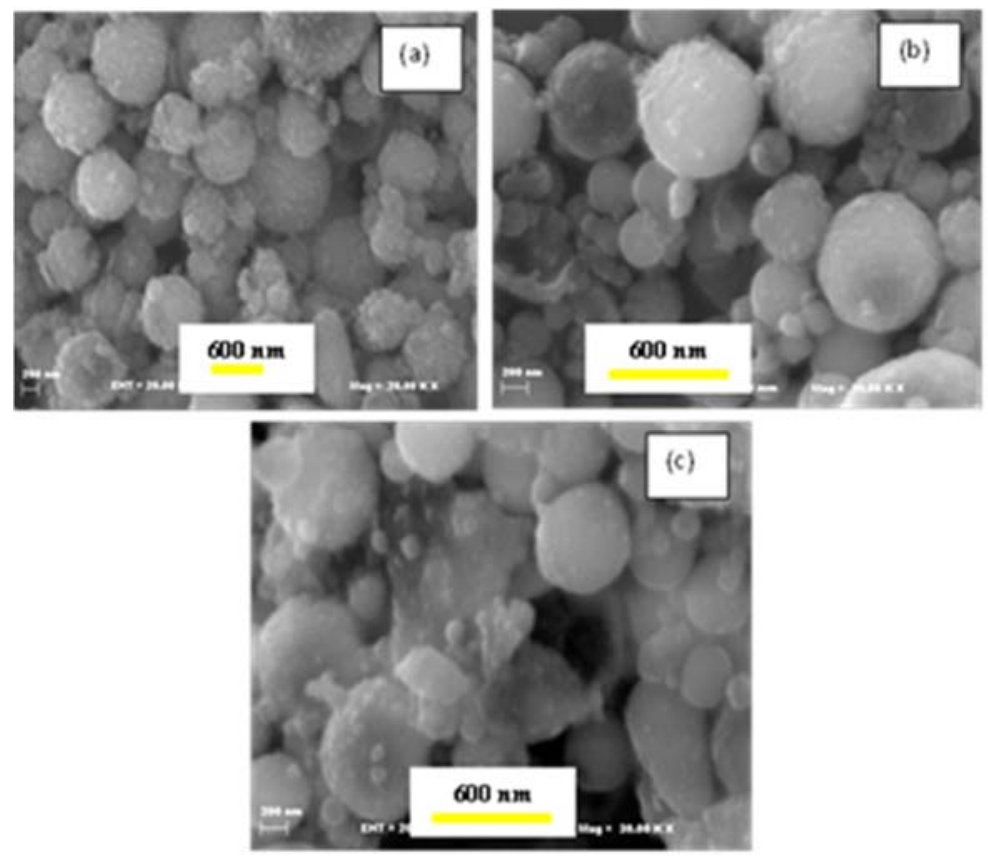

Gambar 6. SEM SEM HAp pada jumlah EG (a) 30\%, (b) 50\% dan (c) 100\% massa prekursor

Gambar 6 menunjukkan morfologi partikel HAp yang disintesis dengan aditif EG. Berdasarkan dari SEM diameter rata-rata dari partikel yang disintesis dengan penambahan EG 30, 50 dan 100\% berat prekursor antara lain sebesar 580, 400, dan 350 nm. Morfologi partikel yang disintesis dengan penambahan EG menunjukkan morfologi berbentuk bola dan tidak teraglomerasi. Penambahan EG dapat menjadi strategi untuk menghasilkan partikel HAp berukuran nanometer. Dari SEM tersebut menunjukkan bahwa meningkatnya jumlah EG yang ditambahkan pada prekursor dapat menurunkan ukuran partikel HAp. Hal ini disebabkan akibat terjadinya dekomposisi dari EG pada temperatur yang tinggi di dalam flame.

Dari pengujian TG-DTA untuk sampel EG menunjukkan bahwa pada pengaruh panas EG akan terdekomposisi menghasilkan gas $\mathrm{CO}_{2}$ dan $\mathrm{H}_{2} \mathrm{O}$. Dari persamaan reaksi dekomposisi EG menunjukkan setiap mol EG yang terdekomposisi akan menghasilkan tiga mol gas. Gas yang dihasilkan dari dekompsisi tersebut selanjutnya akan memberikan tekanan pada dinding partikel sehingga partikel akan terpecah. Hal ini dapat dilihat pada Gambar 6 pada penambahan 30, 50, dan $100 \%$ terdapat partikel kecil yang yang dihasilkan akibat pecahnya partikel besar dimana jumlah partikel yang pecah lebih banyak ditemui pada penambahan aditif $100 \%$.

Berdasarkan Gambar 7 hasil perhitungan menunjukkan bahwa diameter rata-rata partikel HAp yang disintesis dengan variasi penambahan PEG 400 sebanyak 30, 50, dan 100\% dari total massa prekursor masing-masing sebesar 114, 540, dan $599 \mathrm{~nm}$. Dari hasil tersebut menunjukkan bahwa penambahan $30 \%$ PEG 400 merupakan cara efektif untuk menghasilkan partikel HAp yang tidak teraglomerasi dan memiliki ukuran terkecil. Dari segi morfologi partikel dapat dilihat bahwa hampir pada semua konsentrasi aditif PEG 400 ini memiliki berbentuk bulat dengan tingkat aglomerasi yang terlihat sangat jelas pada penambahan PEG 50\% dan 100\%. Hal ini menunjukkan bahwa dengan meningkatkan jumlah PEG yang dilarutkan menyebabkan ukuran partikel meningkat.

Hasil serupa telah dilaporkan Zhang dkk. (2012) pada sintesis HAp menggunakan PEG dengan proses hidrotermal. Bahwa penggunaan aditif PEG dapat mempengaruhi proses pertumbuhan kristal, morfologi, dan ukuran HAp. Semakin tinggi konsentrasi PEG yang dilarutkan maka ukuran partikel dan kristalinitas HAp yang semakin meningkat.

Hal ini disebabkan PEG 400 bersifat sebagai surfaktan non-ionik yang dapat membentuk rantai panjang dalam larutan air serta dapat berperan sebagai template pada proses pembentukan HAp. Melekul PEG dapat membentuk chelate dengan $\mathrm{Ca}^{2+}$. Larutan PEG dalam bentuk PEG-OH mampu menarik $\mathrm{Ca}^{2+}$ yang dilepaskan $\mathrm{Ca}\left(\mathrm{NO}_{3}\right)_{2}$ membentuk ikatan PEG-O-Ca ${ }^{2+}-\mathrm{O}-\mathrm{PEG}$. Selanjutnya, PEG-O-Ca ${ }^{2+}-\mathrm{O}-$ PEG bereaksi dengan $\mathrm{PO}_{4}{ }^{3-}$ yang dilepaskan dari $\left(\mathrm{NH}_{4}\right)_{2} \mathrm{HPO}_{4}$ menghasilkan inti kristal HAp sehingga menyebabkan pertumbuhan kristal lebih cepat (Zhang dkk., 2012).

Selain itu, penambahan PEG di dalam larutan yang mengandung air dapat mengarah pada meningkatnya viskositas dari larutan tersebut (Tello dkk., 1994). Meningkatnya viskositas larutan cenderung meningkatkan ukuran droplet yang dihasilkan pada proses atomisasi oleh ultrasonik nebulizer (Rajan dan Pandit, 2001).

Hasil SEM untuk aditif PEG menunjukkan bahwa penambahan aditif memainkan peranan yang penting terutama dalam pembentukan HAp ukuran 
nanometer pada proses flame. Hal ini disebabkan ketika memasuki zona flame pada temperatur tinggi terjadi reaksi dekomposisi PEG. Proses dekomposisi tersebut disertai dengan pelepasan panas serta produk gas hasil dekomposisi ke dinding partikel HAp.

Berdasarkan hasil TG-DTA menunjukkan bahwa dekomposisi PEG akibat pemanasan akan menghasilkan gas $\mathrm{CO}_{\mathrm{x}} \mathrm{H}_{\mathrm{y}}, \mathrm{H}_{2}$, dan $\mathrm{H}_{2} \mathrm{O}$. Jumlah gas hasil dekomposisi tersebut dipengaruhi oleh berat melekul dari PEG. Semakin besar berat melekul PEG maka gas yang dihasilkan semakin banyak. Sejumlah gas yang dihasilkan tersebut akan menghasilkan tekanan internal pada dinding partikel sehingga menyebabkan partikel terpecah (Purwanto dkk., 2008; Vidyasagar dan Naik, 2016; Kwon, 2006).

Berdasarkan Gambar 8 dari hasil analisa SEM, partikel HAp yang disintesis dengan aditif urea diperoleh partikel berbentuk bulat dan terlihat adanya aglomerasi seiring dengan meningkatnya jumlah aditif urea yang ditambahkan pada prekursor.
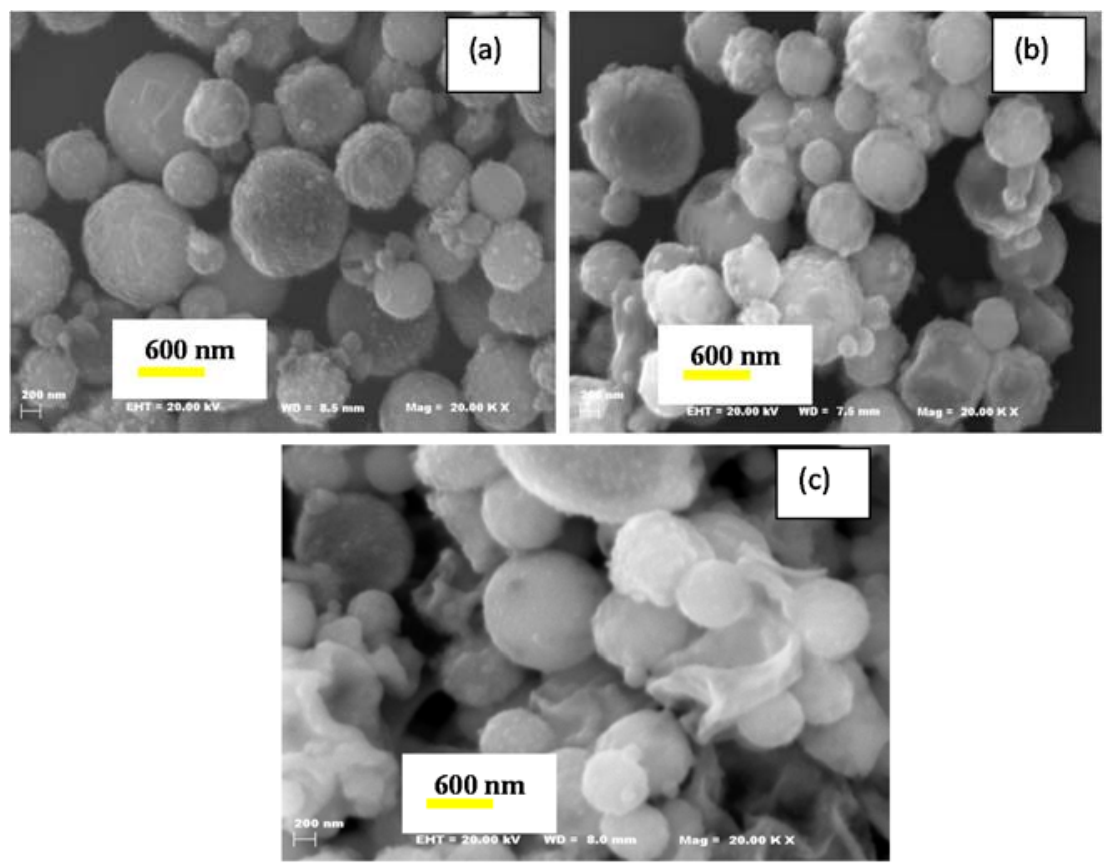

Gambar 7. SEM HAp pada jumlah PEG (a) 30\%, (b) 50\%, dan (c) 100\% massa prekursor
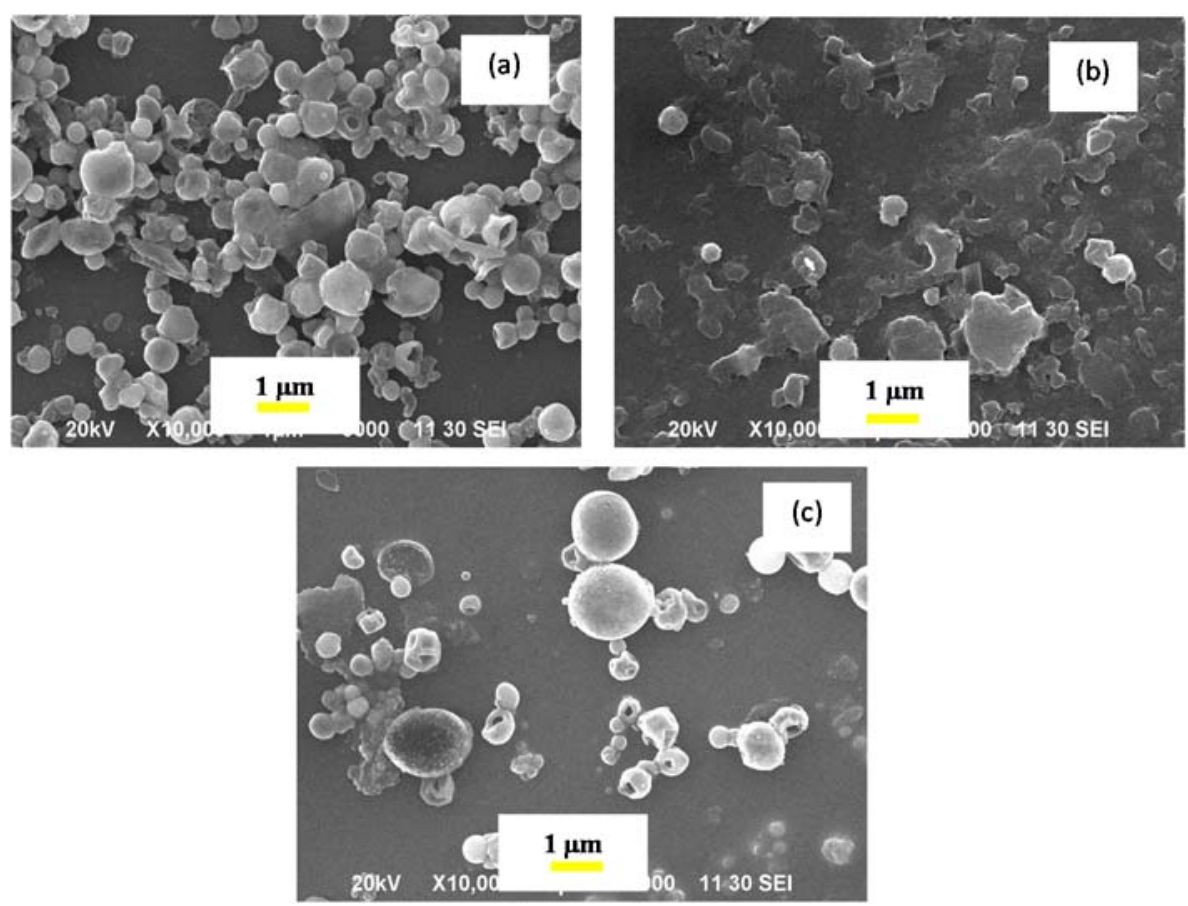

Gambar 8. SEM HAp pada jumlah urea (a) 30\%, (b) 50\%, dan (c) 100\% massa prekursor 
Berdasarkan hasil perhitungan menunjukkan bahwa meningkatnya ukuran partikel HAp akibat peningkatan konsentrasi aditif urea terjadi pada konsentrasi 30 dan 50\% dengan masing-masing ukuran sebesar 162 dan $230 \mathrm{~nm}$. Pada konsentrasi aditif urea sebesar $100 \%$ dari massa prekursor diperoleh ukuran rata-rata HAp sebesar $187 \mathrm{~nm}$. Dari hasil tersebut menunjukkan bahwa penambahan $30 \%$ urea merupakan cara efektif untuk menghasilkan partikel HAp dengan tingkat aglomerasi yang rendah dan memiliki ukuran terkecil.

Pada penambahan aditif sebanyak 30\% dari massa prekursor diperoleh ukuran yang lebih kecil bila dibandingkan dengan penambahan aditif sebanyak 50 dan $100 \%$. Hal ini disebabkan bahwa penambahan aditif urea pada konsentrasi tinggi pada larutan prekursor akan meningkatkan viskositas larutan sehingga proses atomisasi larutan oleh nebulizer akan menghasilkan ukuran partikel yang lebih besar. Hasil penelitian serupa diperoleh oleh Purwanto dkk. (2008) pada sintesis nanopartikel YAG:Ce dengan aditif urea menunjukkan bahwa meningkatkan konsentrasi urea akan meningkatkan ukuran partikel bahkan pada konsentrasi urea yang tinggi aglomerasi dari partikel YAG:Ce semakin besar. Penambahan urea pada prekursor menyebabkan terdekomposisi pada temperatur tinggi menghasilkan asam cyanuric, asam cyanuric, ammelamide, melamin.

Dengan reaksi dekomposisi sempurna menghasilkan gas $\mathrm{NH}_{3}$ dan $\mathrm{CO}_{2}$ pada temperatur $400^{\circ} \mathrm{C}$ sebagaimana mekanisme reaksinya telah dijelaskan sebelumnya pada analisis TG-DTA urea. Dari ketiga jenis aditif yang digunakan, pada penggunaan PEG dengan jumlah $30 \%$ massa prekursor menghasilkan ukuran partikel HAp terkecil yaitu sebesar $114 \mathrm{~nm}$. Dengan menurunnya ukuran partikel HAp maka luas permukaan partikel semakin besar sehingga proses adsorpsi protein akan meningkat dan memperbaiki adhesi sel pada material yang menyebabkan sifat bioactive dan biokompatibilitas akan semakin baik (Brunner dkk., 2006; Stanley, 2014).

Gambar 9 menunjukkan hasil XRD partikel HAp yang disintesis dengan aditif EG, PEG 400 dan urea memiliki kristalinas yang tinggi bila dibandingkan dengan HAp yang disintesis tanpa menggunakan aditif. Hal ini ditunjukkan dengan intensitas peak yang meningkat serta menurunnya FWHM (full width at half maximum) dari kristal HAp. Semakin rendah lebar peak pada setengah intesitas maksimal (FWHM) maka kristalinitas semakin tinggi sehingga ukuran kristal semakin besar (Vidyasagar dan Naik, 2016).

Berdasarkan perhitungan dengan persamaan Debye-Scherrer ukuran kristal terbesar pada penambahan aditif EG, PEG, dan urea sebanyak 100\% massa prekursor dengan masing-masing sebesar 41,2, 34,4 , dan 37,5 nm. Dari ketiga grafik XRD tersebut menunjukkan bahwa meningkatkan jumlah aditif yang ditambahkan pada prekursor akan meningkatkan ukuran kristal. Dengan tingkat kristalinitas yang semakin tinggi akan mengarah pada ukuran kristal yang semakin besar sehingga akan diperoleh produk HAp dengan kualitas yang tinggi.
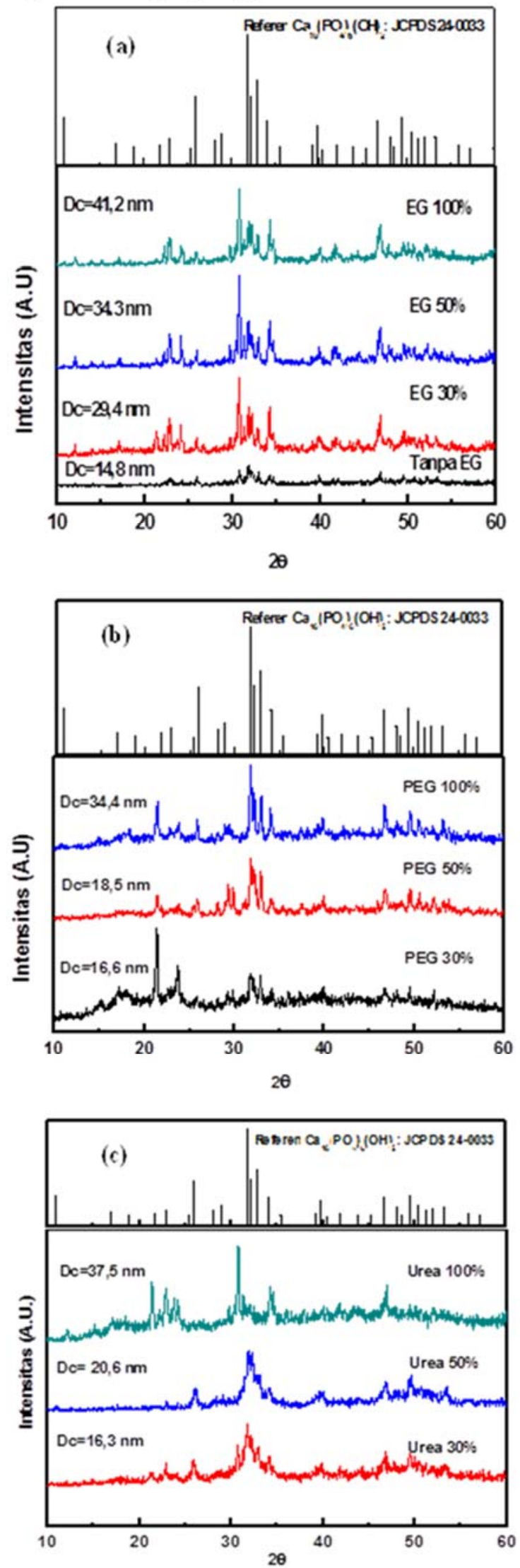

Gambar 9. XRD HAp dengan aditif (a) EG (b) PEG 400 dan (c) Urea 
Analisis DTA menunjukkan bahwa ketiga jenis aditif tersebut akan melepaskan panas pada saat mengalami dekomposisi termal. Pelepasan panas tersebut akan meningkatkan suhu partikel HAp sehingga mengarah pada pertumbuhan kristal menjadi lebih besar. Selain itu penambahan aditif organik menyebabkan pada terjadinya perubahan dalam kinetika pertumbuhan kristal yang menyebabkan laju pertumbuhan dari nuklealisasi semakin cepat dan menyebabkan aggregasi partikel. Oleh karena itu penambahan aditif secara langsung dapat meningkatkan kristalinitas partikel serta dapat mengubah morfologi dari partikel.

\section{KESIMPULAN}

Partikel HAp dapat disintesis dengan penambahan bahan aditif etilen glikol (EG), polietilen glikol (PEG 400), dan urea dengan menggunakan metode flame spray pyrolysis. Jenis prekursor yang digunakan dalam sintesis partikel HAp yaitu $\mathrm{Ca}\left(\mathrm{NO}_{3}\right)_{2} \cdot 6 \mathrm{H}_{2} \mathrm{O}$ dan $\left(\mathrm{NH}_{4}\right)_{2} \mathrm{HPO}_{4}$ dengan perbandingan mol $\mathrm{Ca} / \mathrm{P}$ sebesar 1,67 . Hasil penelitian menunjukkan partikel HAp yang disintesis dengan penambahan bahan aditif organik akan memiliki ukuran yang lebih kecil bila dibandingkan tanpa penambahan aditif. Selain itu meningkatkan jumlah aditif PEG dan urea pada prekursor akan mengarah pada ukuran rata-rata partikel yang lebih besar sedangkan pada penambahan aditif EG menyebabkan ukuran rata-rata partikel mengecil. Hasil terkecil dari partikel HAp yang diperoleh yaitu sebesar $114 \mathrm{~nm}$ dengan ukuran kristal 16,6 nm melalui penambahan aditif PEG sebanyak 30\% massa prekursor. Dari sisi morfologi secara umum meningkatkan aditif hingga $100 \%$ massa prekursor menyebabkan aglomerasi partikel meningkat. selain itu meningkatkan jumlah aditif yang ditambahkan baik EG, PEG 400 dan urea dapat meningkatkan kristalinitas dan ukuran kristal HAp.

\section{DAFTAR PUSTAKA}

An, G.H., Wang, H.J., Kim, B.H., Jeong, Y.G., and Choa, Y.H., (2007), Fabrication and Characterization of a Hydroxyapatite Nanopowder by Ultrasonic Spray Pyrolysis with Salt-Assisted Decomposition, $J$. Materials Science and Engineering A, 449-451, pp. 821-824

Ataol, S., Tezcaner A.E., Duygulu, O., Keskin, D., and Machin, N.E., (2015), Synthesis and Characterization of Nanosized Calcium Phosphates by Flame Spray Pyrolysis, and their Effect on Osteogenic Differentiation of Stem Cells, J. of Nanoparticle Research, 17, pp. 95-108

Brunner, T.J, Wick, P, and Manser, P., (2006), In vitro Cytotoxicityof Oxide Nanoparticles: Comparison to Asbestos, Silica, and the Effect of Particle Solubility, J. of Environmental Science Technology, 40, pp. 43744381
Cho, J.S. and Kang, Y.C., (2008), Nano-Sized Hydroxyapatite Powder Prepared by Flame Spray Pyrolysis, J. of Alloys and Compounds, 464, pp. 282287

Cho, J.S., Jung, D.S., Han, J.M., and Kang, Y.C., (2009), Nano-sized $\alpha$ and $\beta$-TCP Powders Prepared by High Temperature Flame Spray Pyrolysis, J. Material Science Engineering, C, 29, pp. 1288-1292

Cho, J.S. and Rhee, S.H., (2013), Formation Mechanism of Nano-Sized Hydroxyapatite Powders through Spray Pyrolysis of a Calcium Phosphate Solution Containing Polyethylene Glycol, J. of the European Ceramic Society, 33, pp. 233-241

Descamps, M., Hornez, J.C., and Leriche, A., (2008), Manufacture of Hydroxyapatite Beads for Medical Applications, J. of the European Ceramic Society, 29, pp. 369-375.

Fathi, M.H., Hanifi, A., and Mortazavi, V., (2008), Preparation and Bioactivity Evaluation of Bone-Like Hydroxyapatite Nanopowder, J. of Materials Process Technology, 202, pp. 536-542.

Itatani, K., Abe, M., Umeda, T., Davies, I.J., and Koda, S., (2004), Morphological and Microstructural Change During the Heating of Spherical Calsium Orthophospate Agglomerates Prepared by Spray Pyrolysis, China Particuology, 2, pp. 200-206.

Kwon, S.K., (2006), Effect of Process Parameters of UV-Assisted Gas-Phase Cleaning on the Removal of PEG (Polyethylene glycol) from a Si Substrate, J. of the Korean Physical Society, 49, pp. 1421-1427

Mohn, D., Doebelin, N., Tadier, S., Bernabei, R.E., Luechinger, N.A., Stark, W.J., and Bohner, M., (2011), Reactivity of Calcium Phosphate Nanoparticles Prepared by Fame Spray Synthesis as Precursors for Calcium Phosphate Cements, J. of Materials Chemistry, 21, pp. 13963-13972.

Okuyama, K. and Lenggoro, I.W., (2003), Preparation of Nanoparticles via Spray Route, J. of Chemical Engineering Science, 58, pp. 537-547.

Paital, S.R. and Dahotre, N.B., (2009), Calcium Phosphate Coatings for Bioimplant Applications: Materials, Performance Factors and Methodologies, $J$. of Materials Science and Engineering: R: Reports, 66, pp. 1-70.

Pratsinis, S.E., (1998), Flame Aerosol Synthesis of Ceramic Powders, J. of Progress Energy and Combustion Science, 24, pp. 197-219.

Purwanto, A., Wang, W.N., Ogi, T., Lenggoro, I.W, Tanabe, E., and Okuyama, K., (2008), High Luminance YAG:Ce Nanoparticles Fabricated from Urea Added 
Aqueous Precursor by Fame Process, J. of Alloys and Compounds, 463, pp. 350-357.

Rajan, R. and Pandit, A., (2001), Correlation to Predict Droplet Size in Ultrasonic Atomization, J. of Ultrasonics, 39, pp. 235-255.

Sadat, S.M., Khorasani, M.T., Dinpanah, K.E., and Jamshidi, A., (2013), Synthesis Methods for Nanosized Hydroxyapatite with Diverse Structures, Acta Biomaterialia, 9, pp. 7591-7621.

Schaber, P.M., Colson, J., Higgins, S., Thielen, D., Anspach, B., and Brauer, J., (2004), Thermal Decomposition (Pyrolysis) of Urea in an Open Reaction Vessel, J. of Thermochimica Acta, 424, pp. $131-142$

Setiawan, A., Widiyastuti, Winardi, S., dan Nugroho, A., (2014), Kinetika Reaksi Sintesis Biomaterial Hidroxyapatite dengan Prekursor Nitrat dan Asetat, Reaktor, 15(2), hal. 104-110.

'Slósarczyk, A., Stobierska, E., Paszkiewicz, Z., and Gawlicki, M., (1996), Calcium Phosphatematerials from Precipitates with Various Calcium:Phosphorus Molar Ratio, J. of American Ceramic Society, 79, pp. 2539-2544.

Stanley, S., (2014), Biological Nanoparticles and their Influence on Organisms, J. of Current Opinion in Biotechnology, 28, pp. 69-74.

Suzuki, S., Fuzita, T., Maruyama, T., Takahashi, M., and Hikichi Y., (1993), Cation-Exchange Characteristics of Sintered Hydroxyapatite in the Strongly Acidic Region, J. of the American Ceramic Society, 76(6), pp. 1638-1640.

Tello, P.G., Camacho, F., and Blazquez, G., (1994), Density and Viscosity of Concentrated Aqueous Solutions of Polyethylene Glycol, Chemical Engineering Data, 39, pp. 611-614.
Tofighi, A. and Palazzolo R., (2005), Calcium Phosphate Bone Cement Preparation using MechanoChemical Process, J. of Key Engineering Materials, 284-286, pp. 101-104.

Trommer, R.M., Bergmann, C.P., and Santos, L.A., (2009), Nanostructured Hydroxyapatited Powder Produced by a Flame-Based Techique, J. Material Science and Engineering C, 29, pp. 1770-1775.

Vidyasagar, C.C. and Naik, Y.A., (2016), Surfactant (PEG 400) Effects on Crystallinity of $\mathrm{ZnO}$ Nanoparticles, Arabian J. of Chemistry, 9, pp. 507510.

Wang, W.N., Kim, S.G., Lenggoro, I.W., and Okuyama, K., (2007), Polymer Assisted Annealing of Spray-Pyrolyzed Powders for Formation of Luminescent Particles with Submicrometer and Nanometer Sizes, J. of American Ceramic Society, 90, pp. 425-432

Widiyastuti, W., Hidayat, D., Purwanto, A., Iskandar, F., and Okuyama, K., (2010), Particle Dynamics Simulation of Nanoparticle Formation in a Flame Reactor using a Polydispersed Submicron-Sized Solid Precursor, J. of Chemical Engineering, 158, pp. 362367

Widiyastuti, W., Wang, W.N., Lenggoro, I.W., Iskandar, F., and Okuyama, K., (2007), Simulation and Experimental Study of Spray Pyrolysis of Polydispersed Droplets, J. of Materials Research, 22, pp. 1888-1898.

Zhang, H., Liu, M., Fan, H., and Zhang, X., (2012), Carbonated Nano Hydroxyapatite Crystal Growth Modulated by Poly(ethylene glycol) with Different Molecular Weights, Crystal Growth and Design, 12, pp. 2204-2212.

Zhou, H. and Lee, J., (2011), Nanoscale Hydroxyapatite Particles for Bone Tissue Engineering, Acta Biomater, 7, pp. 2769-2781. 